\title{
Who or what is the wali al-amr: The unposed question
}

OÑATI SOCIO-LEGAL SERIES VOLUME 10, ISSUE 5 (2020), 985-1000: HistORICAL AND COMPARATIVE

MACROSOCIOLOGY OF MIDDLE EASTERN LEGAL SYSTEMS

DOI LINK: HTTPS://DOI.ORG/10.35295/OSLS.IISL/0000-0000-0000-1028

RECEIVED 23 NOVEMBER 2018, ACCEPTED 01 MARCH 2019

\section{NATHAN J. BROWN* (D)}

\section{Abstract}

Modern Islamic political thought has grappled with the nature of state authority by using and reshaping the tools of classical legal and political thought. That is a tradition that gives rich guidance on what a ruler should and should not do, but it gives much less certain guidance (and all but renders invisible) the questions of administration and policy. The wali al-amr - the head of the community (a term identical to the one used for legal guardian over a minor) - has been transformed from an individual ruling to a modern bureaucratic and policy state in Islamic political writings without that transformation drawing notice. This paper explores the resulting ways in which Islamic practices and concepts, developed for a rudimentary state apparatus focused on public order, care for the poor, and some urban public services, operates in a world in which states administer and develop policy over a wide array of public affairs.

\section{Key words}

Islam; policy state; Islamic governance

\section{Resumen}

El pensamiento político islámico moderno ha lidiado con la naturaleza de la autoridad estatal mediante el uso y la remodelación de las herramientas del pensamiento político y jurídico clásico. Esa es una tradición que brinda una guía útil sobre lo que un gobernante debe y no debe hacer. Pero, si es útil para la ética del gobierno, brinda una orientación mucho menos segura (y se vuelve casi invisible) en lo tocante a las cuestiones de administración y política. El wali al-amr -el líder de la comunidad (un término idéntico al utilizado para el tutor legal de un menor de edad)-, ha pasado de significar un fallo individual, a un Estado burocrático y político moderno, sin que la

\footnotetext{
* Nathan J. Brown is professor of political science and international affairs at George Washington University and non-resident senior fellow at the Carnegie Endowment for International Peace. He is author most recently of Arguing Islam after the Revival of Arab Politics (Oxford University Press, 2017). Contact details: Elliott School of International Affairs, George Washington University, Washington, DC 20052 USA; email address: $\underline{\text { nbrown@gwu.edu }}$
} 
transformación haya sido advertida. Este artículo explora las formas resultantes en las que las prácticas y los conceptos islámicos, desarrollados para un aparato estatal rudimentario, operan en un mundo en el cual los Estados administran y desarrollan políticas en una gran variedad de asuntos públicos.

Palabras clave

Islam; estado político; gobernanza islámica 


\section{Table of contents}

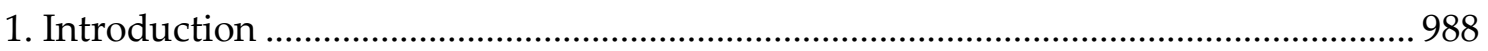

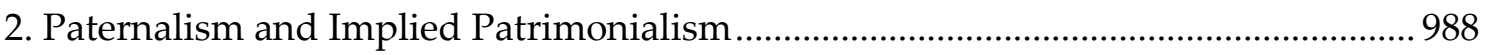

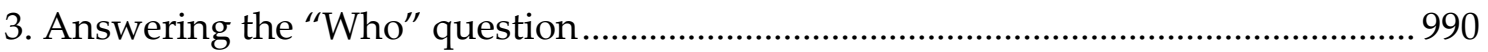

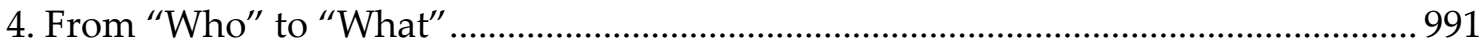

5. Grappling with "What" while actually talking about "Who" ...................................... 992

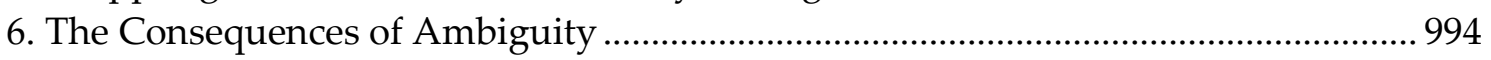

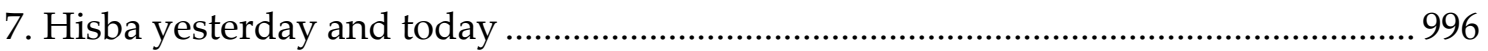

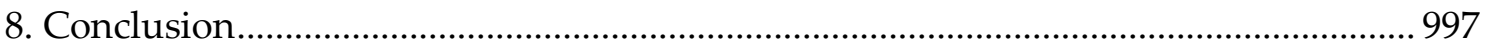

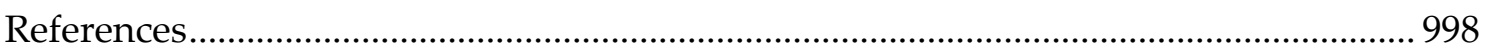




\section{Introduction}

On the last day of 2017, the Mufti of the Republic in Egypt, Shawqi 'Allam, issued a fatwa against trading in Bitcoin. ${ }^{1}$ The reasoning was legal and religious but included a set of unmistakably political judgments - among other reasons, it was forbidden since Bitcoin undermined the ability of the Egyptian state to regulate, allowed traders to escape security agencies, and could be used by $D a^{\prime} a s h$ [ISIS] -. In one sense, the mufti was drawing on an Islamic jurisprudential tradition that dated back over a millennium. To do so, he translated a set of classical concepts into a thoroughly modern setting. The need to answer modern questions was most obviously the case with Bitcoin itself, a cryptocurrency.

Much less obviously but much more importantly, the Mufti was referring to other modern structures completely unanticipated in that classical vocabulary in which he sought to ground his opinion - for fiscal policy (such as central banks), a political system (the modern administrative state), and even his own bureaucracy (Dar al-Ifta'), endorsing their legitimacy. In fact, the Mufti boldly made compliance with their policies and acceptance of their legitimacy a matter of the Islamic shari'a. And more remarkably, he did so without the feeling the need for any elaborate reasoning - or any reasoning at all, in fact--concerning any of these structures. He simply referred to the issuing of currency as a duty of the wali al-amr, one of the terms the classical literature can use for a ruler.

Such elision between a vast state apparatus and a single ruler is remarkable not only for its boldness but also for its unacknowledged nature and therefore the way it renders the modern state simultaneously inevitable and invisible. In this paper, I seek to explore how this elision takes place and what its implications are. And I will do so through exploring the generally unexamined leap between the wali al-amr and the modern state.

When writers today draw on the Islamic legal and political tradition to consider matters of political authority, they can draw on that tradition to refer to rulers, states, and sovereign bodies in a number of ways. Perhaps the most common term is the "wali alamr," which might be roughly translated as "guardian," "authority," or arguably "fiduciary" - the person or entity entrusted to act on behalf of the interest of another party.

Who or what is the wali al-amr? The answer to that question is telling but perhaps even more telling is how infrequently the question is asked. I will begin by exploring what the term means and then explore its focus on individuals rather than institutions. The next section will examine the institutions that embody the concept of wali al-amr before proceeding to a section examining how the shift from individual to institution has not been reflected in current political discourse. I will close by probing the implications of this invisible elision.

\section{Paternalism and Implied Patrimonialism}

The term "wali al-amr" itself is used today in two very different (or perhaps not so different) contexts. First, it might refer to a legal guardian (such as a parent of children)

\footnotetext{
1 The fatwa, widely discussed in the press, is fully summarized and paraphrased on the website of Dar alIfta' al-Misryya (Dar al-Ifta' Media Center 2018).
} 
authorized to act on behalf of another individual. Second, in a term evoking the quite literally paternalistic connotations of the first context, the "wali al-amr" might be the individual or institution responsible for the political community; it is the official, set of officials, or state institutions that is entrusted to deal with an issue on behalf of the community.

Seen this way, it is not clear what the right question is to ask. Should we inquire "Who is the wali al-amr?" Or is "What is the wali al-amr?" the better question? The term might refer either to an individual or an institution. That distinction rarely receives attention.

And that inattention begs for attention. Why does nobody notice the shift? The underlying question "should those looking for the wali al-amr be looking for a person or an institution?" would seem critical but is almost never posed.

Scholars schooled in the need for precise analytical definitions might feel a strong sense of frustration at this point. The unasked who/what question suggests not merely that the same term might be used in such two different contexts, one personal (guardian of a minor) and the second political (a ruling person or institution). Much more than that, the second, political context tosses together individuals and institutions in a confusing mix. Is the wali al-amr the head of state, the parliament, the constitutionally and legally authorized bodies, or the particular state official entrusted to deal with a specific issue?

Which of these captures current usage? The answer is yes. It is any and all of these.

This was brought home to me when I worked with a colleague to translate a 1995 decision by Egypt's Supreme Constitutional Court (SCC) in a case involving women's head covering (Brown and Lombardi 2006). The Minister of Education had barred the niqab (full face veil) from Egyptian schools; the father of two sisters expelled under the ban, acting as the wali al-amr (legal guardian) for them, filed suit against the principal, the school, and the minister. He claimed the ban violated Article 2 of the Egyptian constitution which states that "the principles of the Islamic shari'a are the main source of legislation." The SCC turned back the challenge, arguing that in matters of the Islamic shari'a, except for those few rules certain with regard to their authenticity and meaning, the wali al-amr is authorized to enforce the interpretation consistent with the general goals of the Islamic shari'a that is most appropriate for the society at that time.

In the court decision, the justices use the phrase "wali al-amr" to refer both to the father (because he acts legally on behalf of the students who are expelled) and the ruling political authority. But in this latter sense, it seems to refer at various times to the ruler, the minister of education, the court, the parliament, the constitutional authority, the entire state, or any state authority. The justices shift among these bodies implicitly without feeling any need to state explicitly which one they mean; it is clear who or what the wali al-amr is only from the context. In seeking to ground their reasoning in Islamic political and legal terminology, the SCC has neither the language nor the interest in expending any verbiage distinguishing among these things.

The justices of the SCC are not alone in taking this stance but instead are following a hoary tradition. Classical Islamic political thought - and much scholarship on the traditions of Islamic legal and political thought - focuses considerable attention on the office holder but little on the institutions of governance; the political systems in which 
they emerged were ones that often had many institutions but possessed few of the structures and followed few of the practices of the administrative and bureaucratic state.

In the past two centuries, vast administrative and bureaucratic states have been built in the Middle East drawing on a number of traditions - the Persian and the Ottoman to be sure, but also the continental European. When those states were built - generally in the nineteenth but especially the twentieth century - much older vocabulary was deployed more energetically and in new ways (including dawla, siyasa, and qadi); other terms continued in usage but lost their prominence (such as hisba; ahl al-'hall wa-l-'aqd); still other words fell by the wayside retaining only historical and little contemporary institutional expression in all but a few political systems (sultan, imam, and khalifa).

\section{Answering the "Who" question}

Attempts to render classical Islamic political concepts into the vocabulary of modern Western politics is an old tradition among Western scholars and political thinkers. Some of the earliest efforts by Western academic scholars to explain the practice of the early Islamic community - those of seventh-century Medina but also those of the later caliphate - do so in a manner that shows special interest in questions that arise in Western constitutional traditions: relationship between religious and political authority, the nature of freedom, the injunction to consult, or the criteria for selecting a ruler (Watt 1998). Other academic efforts looked not so much to practice but to theory - to what extent Islamic legal and political thought resembled that of modern Western (especially liberal) political thought.

In recent years, the comparative focus in which Islamic terms are translated into Western political concepts seems to have declined among scholars without being abandoned. Stilt's examination of the doctrine of hisba and the post of muhtasib focuses as much on ideas of discretion and delegation instead of only explaining these ideas and practices in modern Western terms of accountability and policing (Stilt 2012). Anjum's revisionist arguments regarding the development of Islamic legal thought directs our attention to an attempt to build a shari'a-based conception of the political in the medieval period (which he associates with Ahmad ibn Taymiyya), one which survives into the modern period (Anjum 2012).

Yet even this scholarship hardly focuses on institutions and largely ignores procedures: it explores intellectual traditions, the ethics of rule, the derivation of law, specific offices (judge, mufti, muhtasib). But they leave only the vaguest ways to approach modern administrative and legal structures, like no audit bureaus, ministries of housing, state broadcasting authorities, pension bureaus, pretrial detention, and courts of appeal. There is simply little sense that there is a complex bureaucratic, regulating, and policing entity like the modern state. Office holders and offices are not distinguished, chains of command, clear lines of authority, relations among ruling structures, and procedures for making rules and designating officials are largely passed over in silence.

The closest consideration of the interaction of complex institutions in the classical tradition may come from the "circle of justice" grafted onto the Islamic political tradition (Darling 2013). And even the circle of justice places much emphasis on wisdom, balance, and virtue - traits that inhere more in the individual than the institution - and precious little on procedure. Authority might be delegated in a patrimonial fashion (from ruler to 
muhtasib, for instance) but it is rarely regulated. There is, to use a term fashioned for a very different context, a "unitary executive." 2

In this respect, the increasingly radical critique advanced by Wael Hallaq - which began with a claim that the Islamic shari'a as it was understood in the pre-modern period has been lost (Hallaq 2004) and has evolved to the claim that the Islamic shari'a and the modern state are incompatible in their very essences (Hallaq 2014) - misses the point. In advancing this view, he asserts a claim to absolute sovereignty by the modern state but simply passes over much of what the state actually does; significantly, his portrait relies more heavily on Carl Schmitt than Max Weber (and he treats Weber's emphasis on rationality and bureaucracy as both incomplete and an aspect of domination).

The movement from individuals and offices to complexes of institutions is neither sudden nor wholly new. The Ottoman Empire bureaucratized the religious realm in a manner that has been bequeathed to many of its successor states, with a hierarchy of religious scholars, an office of the Shaykh al-Islam that evolved into state muftis and ministries of religious affairs in the twentieth century. The Ottomans left behind a religious establishment that existed in a form very consistent with the bureaucratic patterns of a modern state without a new language for explaining itself.

\section{From "Who" to "What"}

When the wali al-amr is the ruler, it may seem obvious to focus on what qualities are necessary to exercise authority in a righteous manner, beneficial to the community. The elision between "ruler" and "dad" may be less of a leap. But when the wali al-amr is a modern, administrative state, a focus on ethics, piety, virtue, and character seems at best only the start of a political theory.

Bureaucratic states have vast and extensive structures and they wade (or plunge) into the religious realm whether by design or not; when religion is understood not simply as a matter of personal faith but a way for structuring social practice, it naturally encounters and becomes intertwined with political authority. That political authority manifests itself not only in a ruler but in a set of officials, structures, institutions, procedures, and practices that can rarely be reduced to an individual will. Middle Eastern states generally eschew even a formal commitment to the exclusion of the religious realm from matters of state.

So religion and the state are baked together. But that simply multiplies the questions that need to be answered: How are identification cards supposed to register religion? How are endowments for charities to be audited? How should grades in religion classes be factored into students' academic records? How many minutes should sermons last? What are the plumbing requirements and electrical wiring regulations for constructing a mosque - and who decides who may lead prayers and give sermons? What should sermons say? How long can they last? What must they say? What can they not say?

These are all issues on which Middle Eastern states weigh in. And they do so not solely as the expressions of a unitary will. Though regimes and rulers do certainly make clear their positions on these questions on occasion, there are also local officials, specialized

\footnotetext{
2 The term comes from an interpretation of Article Two of the United States Constitution which states: "The executive Power shall be vested in a President of the United States of America."
} 
committees, and unknown bureaucrats that color within the very general lines laid down by those at the top. States act through complex structures that have their own institutional patterns, practices, and interests - and often ones that trip over each other as the regulate, police, and monitor religious matters.

But in speaking about the religious aspects of the modern state, the vocabulary usedby figures within the institutions themselves, the broader public, and scholars-reflects the older usage even as individual officials have evolved into complex institutions. A mufti is a learned figure who answers legal questions. By contrast, state muftis are structures that might variously provide binding interpretations or guidance to official bodies, answer questions in a non-binding way to members of a pious public, counter violent extremism, take part in international diplomacy, and review death sentences all in a manner regulated by law (Skovgaard-Petersen 2004). Judges hear cases and issue verdicts. But in a modern state, judges are part of judicial structures and rule on the basis of complex legal frameworks, do so in multi-judge panels, find their verdicts subject to appeal in hierarchical systems, operate according to a set of procedures designed by ministries, judicial councils, and other official bodies, and adjudicate on the basis of codes, legislation, and regulation, some of which might draw on the Islamic shari'a but that rarely depend on judicial training in figh. Commanding the good and forbidding evil - hisba - is not a task for the president, king, or prime minister to undertake personally any more, nor is there a designated individual to serve as muhtasib. But there are structures: the "religious police" in Saudi Arabia remain the clearest example of a bureaucracy that steps into the role of muhtasib (Mouline 2014). And there legally encoded mechanisms (the entrusting of legal actions based on hisba to the public prosecutor in Egypt (Agrama 2012) that transform the practice from an individual mandate to a bureaucratic function.

Religions involve matters on which modern states are active and sometimes quite precise. When studying, praying, lecturing, assembling, celebrating in a religious manner, often a state bureaucracy (or set of bureaucracies) is an active presence in the room, regulating, policing, monitoring, teaching, and guiding.

\section{Grappling with "What" while actually talking about "Who"}

Using older vocabulary (that refers to persons) to refer to bureaucratic state practices and functions has costs. It obscures the way in which seemingly old questions are actually being posed in new ways. Islamists - understood not in the sense of formal political movements but instead to refer to those who wish for a political order based on their understanding of Islamic principles - often seen at a loss for precisely this reason.

Actually, the conflation between individual and institutional itself is actually not wholly new: Islamic societies had all sorts of institutions (judiciaries, militaries, ruling courts, schools, courts, academies of learning, and guilds/schools of jurisprudence (madhahib). And those who dwelt on political questions certainly recognized the need to discuss the authority of each and the relationship between them - but in doing so, theorists tended to focus on them as personified by individuals: ruler, judge, scholar. ${ }^{3}$ As the state has

\footnotetext{
${ }^{3}$ In this regard, it is instructive to read Mohammad H. Fadel's (2017) recent translation of Shihab al-Din Ahmad ibn Idris al-Qarafi al-Maliki's Al-ahkam fi tamyiz al-fatawa ‘an al-ahkam wa tasarrufat al-qadi wa-l-imam.
} 
grown far more complex, that tendency has survived, making the older conflation no longer simplifying but instead quite confusing.

In the late 1970s, the Research Academy (majma' al-buhuth) of al-Azhar, the most authoritative scholarly body within the sprawling institution, drafted a constitution for an Islamic state. ${ }^{4}$ The document makes some concessions to the structures and vocabulary of most modern states, referencing elections, a parliamentary body, and a smattering of rights and regulatory areas. But it strives to maintain older Islamic vocabulary (the leader is an imam) and substance (many of the provisions are guided by or bounded by the Islamic shari'a). Reading the document in light of other written constitutions, it seems quite skeletal in what it covers; most constitutional lawyers and scholars would find it hopelessly vague on a host of procedural and substantive questions.

Three and a half decades later, a set of constitutional drafting efforts in Egypt pulled in al-Azhar once again in a very different manner - this time not in an aspirational project of sketching out what a constitution for an Islamic state might look like but instead how Egypt should be governed at a time of unprecedented contention and upheaval. AlAzhar was both a participant in the struggles (taking positions on how the document should provide for the Islamic shari'a and especially on al-Azhar's role) and an object of struggle (since various political forces regarded the institution as a prize to be won, a possible ally, or a bulwark against rivals).

On this occasion, what was striking was how little anyone (even Islamists and Azharis) seemed interested in reviving the document from the 1970s. And indeed, the goal of the institution itself seemed to jettison any influence over the document as a whole and instead focus its efforts on provisions that would insulate it from the constitutional struggles, grant it a pledge of autonomy, and avoid any significant formal constitutional role. To be more precise, Al-Azhar's leadership did not at all shy from exercising a leading role in Egyptian society, but it saw the effort to constitutionalize that role as one that might be confining or - if it was too ambitious - make al-Azhar a political target (Lombardi and Brown 2012).

What is notable about this evolution - from an attempt to draft an entire constitutional document to an effort to extricate itself from an actual constitutional text - is that it seemed to be guided by a political logic utterly unrelated to Islamic jurisprudence or classical vocabulary. Al-Azhar's leaders played politics well, but when they did so, their calculations were informed by the immediate political context just as much as any other actor; when making the translation from classical Islamic legal and political thought to modern constitutional text, there was little to guide their decisions except short-term tactics similar to those used by some other state institutions (like the judiciary).

Islamic legal thinkers who have dealt with constitutional questions have shown little interest in procedural instruments of accountability, trusting instead in Islamic law and personal virtues. Taqi al-Din al-Nabahani, the Palestinian founder of the Islamist Hizb al-Tahrir drafted a constitution for an Islamic state in the 1950s that stated starkly "The president of the state is the state" (Al-Hasan 1989). Four decades later, when testifying

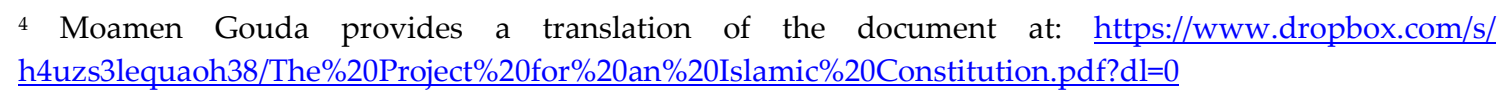


in the case of the killing of Faraj Fuda, an Egyptian secularist intellectual, Shaykh Muhammad al-Ghazzali stunned the courtroom by proclaiming anyone who made statements like Fuda had uttered to be an apostate. Much less noticed, he also insisted the penalty had to be inflicted by a legitimate authority. And then, most tellingly, he lost all ability to give definitive guidance on constitutional questions: when asked what would happen if the ruler failed to act, he gave no remedy; when asked what would happen if an individual took matters in hand and killed the apostate, he refused to endorse such vigilante action but also stated there was no penalty for it. ${ }^{5}$ He knew an apostate when he heard one but had only the most indeterminate guidance about how to apply that judgment.

Over the centuries, jurisprudential debates have probed when one can change with the hand, tongue, and heart and who may do so. But they have had nothing to say about votes of confidence, judicial review, or elections; jurists have had advice on the duty and the method of correcting the ruler but no guidance on how to amend the constitution. When politics is personal - when the ruler is a person rather than a thing - structural and procedural questions do not suggest themselves very readily.

And that shapes the nature of political debates. When Islamists of various inclinations today argue about the course of political action, a critical difference among them centers on the legitimacy of the ruler: is he misguided and mistaken (and thus in need of correction) or irreparably unjust (and perhaps a legitimate target for rebellion). The distinction among quietist, reformer, and jihadist often hinges on this political judgment. And most of the debate focuses not on how a ruler achieved authority but instead on what he has done; the procedural legitimacy that figures so central in many modern constitutional orders gets at most formalistic attention not simply in pre-modern political thought but in debate among Islamists today.

To be sure, that is beginning to change in some more detailed recent discussions. AlAzhar took a far more sophisticated position in the constitutional debates of 2012 than it had decades earlier, focusing as has been seen far more attention on the fine print of provisions regarding the institution itself rather than general provisions about the Islamic shari'a. And in the period before 2011, Islamists in Egypt debated whether or not women could hold the position of judge or head of state. Those who held close to traditional fiqh insisted such positions could only be held by a male. But others within the Islamist camp began to argue that such positions were based on an outmoded premodern conception of those positions (in which the ruler, for instance, served as prayer leader).The call for revised interpretative approaches was often heard but it came in an interesting way: it was argued traditional fiqh did not anticipate the modern state in which such offices were better seen not in personal terms but as institutions who might be staffed with different individuals.

\section{The Consequences of Ambiguity}

There is nothing distinctly Muslim about the deployment of pre-modern vocabulary to understand institutions and practices of the modern state. Many basic terms used to

\footnotetext{
5 See Al-Ghazzali: No Punishment in Islam for Anyone Who Kills an Apostate, in al-Hayah, 23 June 1993. For one summary of the testimony mentioning these points, see Isma'il 2016.
} 
describe states, regimes, and political systems throughout the world (dictatorship, oligarchy) by specialists and non-specialists, were developed in a classical Mediterranean world in which authority was generally understood as directly exercised directly by individuals; even a democracy was one in which a people assembled made decisions (with offices, when necessary, sometimes distributed by lot on the premise that citizens are interchangeable.

And the elision between individual and institutions is also not uniquely Islamic. The term "unitary executive" referenced above stems from the United States Constitution's reference to the executive authority as a person. But while widespread, such terminological elision can cause conceptual problems (among scholars on how to define democracy, for instance; see Brown 2011) and constitutional controversies (during the administration of George W. Bush, for instance, on presidential authority). ${ }^{6}$ And it seems particularly pronounced in questions involving political authority in the Muslim world today.

Indeed, we might fruitfully pause here on the very word "authority," since among those who seek to draw on Islamic political and legal thought, the problems and controversies might best be rendered in English (though ironically not in Arabic) by a juxtaposition of two senses of authority that arise in such discussions. What we often refer in English to as "religious authority" - especially in Sunni Islam - is the ability to speak with expertise, learning and training on questions that arise. But "authority" in the political sense carries a very different meaning of being able to make efficacious decisions. The first authority is moral in nature; the second can pack a physical punch.

Thus, the issue for much modern Islamic political thought is often the relationship, even the tension, between the two kinds of authority. Many of the issues that arise thus might be ascribed to the institutional and procedural ways (or lack thereof) in which religious and political authority interact. Debates over personal status law, for instance, are not simply over interpretation and text but who should be interpreting texts and how; debates become bitter because they involve not only the conclusions about divorce and custody but how to get to those conclusions and who is qualified to lead the way (El Muhtaseb et al. 2016).

In a recent work, Ali Gum'a, Egypt's former state mufti, narrated the legislative history of Egypt, many references to what he calls "the modern state" point not to bureaucracy and complexity but instead to legislation (and implicitly to embrace of economic development as a policy objective). Only occasionally are specific structures mentioned, and even then, they can be referred to as almost abstract and timeless entities (such as the military) rather than structures (such as the Ministry of Defense or the Supreme Council of the Armed Forces) that have been remade and expanded in the modern era. In the work, he seeks to show how Egypt's legislative framework is consistent with and even based on the Islamic shari'a (Jum'a 2008).

The way in which the Egyptian state has regulated, policed, and monitored the religious field; the manner in which various arms of the state interact; or questions of budgeting receive no mention from the venerable scholar. And Egypt is hardly alone here in the

\footnotetext{
${ }^{6}$ For a very brief summary of the issue, see Sunstein 2007.
} 
way in which the state and the regime have entered and worked to remake the religious field (on Morocco, for example, see El Katiri 2013).

\section{Hisba yesterday and today}

For a subtler example, we can return to the doctrine and practice of hisba, commanding good and forbidding evil-a task for the community according to the Qur' an ${ }^{7}$ - and one that Islamic legal and political thinkers saw as the primary duty of the ruler of the Muslim community. For present-day political purposes, distinguishing between good and evil is the easy part. The obvious difficulty is figuring out who is supposed to be undertaking this task - individual or ruler. But the really knotty problem in recent years has been the bureaucratic one - if the ruler is going to undertake hisba, which structures should do and what procedures should they follow?

Let us turn to the obvious problem first, the relationship between the individual and the community (as led by the ruler). Andrew March writes on the topic, "While ultimate sovereignty belongs to God, the execution of that sovereignty - 'commanding right and forbidding wrong' - is seen as dispersed in the Muslim community at large, even at the level of the individual pious Muslim. There is a radical populism in the Islamic theocratic imaginary." But he goes on to say "Indeed, the most prominent classical Islamic thinkers who wrote on hisba (...) insist that 'commanding right and forbidding wrong' is the single foundational principle of all Islamic political authority (...)" (March 2015, 847). The role of the individuals, the community, and the ruler is one that did receive attention - enough over the years to be summarized in English-language scholarship in a rather lengthy book (Cook 2010).

But acknowledging the role for the ruler leads to the really thorny - and underexamined - questions for the modern state. In Egypt until recently, the term "hisba", when used in a legal context generally referred to guardianship of minors. But it also allowed individuals to bring cases representing good and evil-or public order and morality directly to the case. In the most famous example in recent years, Islamist legal activists resorted to the court when Nasir Hamid Abu Zayd, a Cairo University professor who wrote a book they deemed blasphemous, to have his marriage to his wife dissolved. They argued that Abu Zayd was no longer a Muslim and thus his marriage to a Muslim woman was legally invalid - a case they eventually won (Agrama 2012).

There are very difficult issues here - the standards used for apostasy; the ability and authority of the courts to adjudicate the issue; constitutionally-enshrined principles such as freedom of creed (Brown 2019) - and the Egyptian state found a way to avoid confronting any of them by a simple procedural change. After all the controversy surrounding the Abu Zayd case, parliament was persuaded to amend the law to have hisba complaints go not directly to a court but instead to the public prosecutor who could then decide whether or not to pursue the case. A repetition of the Abu Zayd case can be avoided not be new understandings of good and evil or of the nature of Islamic governance but instead through shuffling chains of command among state officials.

\footnotetext{
7 The Qur'anic verse (3:104) reads:

Let there be among you an ummah calling to good and [they] command what is right and denounce what is wrong).
} 
In Saudi Arabia, the official body that is delegated to carry out this work - the Committee for Promoting Virtue and Prohibiting Vice (CPVPV), often referred to as the "religious police" in English - has been reined in through a similar bureaucratic sleight of hand. While the CPVPV portrays itself as the enforcement of public morality in Saudi Arabia, it does so by citing the deputation by the king. And in recent years, the authorization for its activities has been increasingly formalized, with a series of regulations and specifications of bureaucratic structuring guiding its activities. ${ }^{8}$ And it was precisely that bureaucratic framework that made a fundamental change in the CPVPV's role possible in 2016 - a move that had no ramifications in terms of Islamic jurisprudence and for which the tradition of Islamic political thought gave no guidance. The CPVPV's regulations were amended to direct its members to report violations to the regular police rather than detain individuals or use coercive means itself. By tinkering with its authority, Saudi Arabia's rulers insured that "religious police" could no longer police but instead became a bureaucracy that could only nag and cajole; its members could enjoin virtue as much as they liked but could no longer do more than nag if they wished to prevent vice. Further changes were contemplated that would have accentuated this change, such as shifting the CPVPV from a freestanding body deputized by the king and reporting to the cabinet to an arm of the Ministry of Religious Affairs or the Ministry of Interior (see Brown 2017).

Around the same time, Saudi rulers prepared other changes that portended major shifts in the role of Islam in public life through minor, seemingly technical changes. Saudi judges were asked to write down their rulings on major questions and legislation was drafted to allow graduates of law school (and not merely shari'a faculties) to join the judiciary if given additional shari'a training. The impact of these reforms would be apparent to any student of the modern Saudi state and would be no surprise to anyone familiar with modern legal systems and bureaucracies. They would remove much of the discretion from individual judges; weaken the link between the judiciary and specific sectors of Saudi society; and enhance the sense that Saudi courts are arms of the state. The slow shift of the Saudi Diwan al-Mazalim from a body that presents itself as an heir to a classical tradition of offering subjects redress of grievances to one whose members explain that they are a precise counterpart to Egypt's administrative courts has followed a similar path. Saudi Arabia's rulers have reined in religious actors and reduce their discretion, transferring authority over interpretation and application subtly and profoundly to senior executive branch officials, many without much formal training in Islamic jurisprudence.

\section{Conclusion}

Discretion has always been a critical issue for Islamic law in action (Stilt 2012). But the core political, constitutional, legal, and regulatory issues involved for discretion in a modern state - who is allowed to do what; whose interpretations of rules matter; what to do when rulers or interpretations conflict - are obscured when authority is viewed as unitary (if sometimes delegated) and personal.

\footnotetext{
8 These are posted on the CPVPV's website, https://www.pv.gov.sa/Pages/PVHome.aspx, accessed January $18,2018$.
} 
In one prominent case, of course, the confrontation between classical legal theory and the structure of the modern state was played out over a short period of time and full public (even international) attention. The decision of the revolutionary leadership of Iran to build an "Islamic Republic" based in part on Ayatollah Ruhollah Khomeini's interpretation of wilayat al-faqih raised enormous constitutional, practical, and bureaucratic questions. These issues were wholly unanticipated in Khomeini's prerevolutionary teachings, which envisioned a jurist who could lead on all legalpolitical questions and a bureaucracy that merely implemented instructions in a clerical fashion. Were operating a modern state so simple, Iranian political history after 1979 would be much have been much less contentious.

The way in which Arab states with Sunni majorities have grappled with issues of Islam in the modern state have been less dramatic and received far less attention. And the fact that the struggles have happened subtly means that there has been little discussion about them. But the implications are far reaching. It is not that old words and concepts are irrelevant but instead that they take on meanings that are subtly but profoundly different from their original ones. A fatwa, for instance, has shifted from an individual response to a believer's question - and, at time, a mode of transmission for Islamic legal teachings and rulings and a dialogue among specialists - to a collection of diverse things, such as products of bureaucratic structures, modes for arguing about Islamic law in public, or contests between official and non-official actors on religion in public life (Caeiro 2013, Brown 2016).

For those who seek to bring Islamic religious teachings to public life, maybe the answer is to make virtue out of necessity - or, more precisely, to infuse necessity with virtueby developing an Islamic ethics of public administration for the pious who seek to operate within a modern state, an ethical guide that embraces the focus on the individual rather than pretending that the leap from the personal to the institutional is effortless. The alternative is to build an Islamic constitutional theory on classical thought or perhaps by a reexamination of the early Islamic political tradition (and documents such as the Constitution of Medina) - a path that is not only indeterminate (as the controversy over 'Ali 'Abd al-Raziq's Al-Islam wa-l-Usul al-Hukm, 1925) showed long ago and that places weight on those documents and traditions that they are simply unlikely to bear (Emon 2001).

And for those who do not seek to cast their contribution as one of the faithful but instead to develop comparative understandings, one promising path may be to develop understandings of Islamic political thought as participating in a much broader set of attempts to wrestling with old questions involving fiduciary nature of state authority in modern contexts (Fox-Decent 2011).

And more broadly, for the scholarly community that does not base its contributions on a shared religious commitment to Islam and that seeks more to understand rather than prescribe, the conclusion is not simply that Islamic political vocabulary obscures the way in which Islamic legal and political teachings are remade in the modern state; it is that the vocabulary actually directs our attention in the wrong directions.

\section{References}

'Abd al-Raziq, 'A., 1925. Al-Islam wa-Usul al-Hukm. Cairo: Matba'at Misr. 
Agrama, H.A., 2012. Questioning Secularism: Islam, Sovereignty, and the Rule of Law in Modern Egypt. University of Chicago Press.

Al-Hasan, S., 1989. The Concept of the Rules of Public Order in the Political Thought of Hizb alTahrir. M.A. thesis, Department of Economics and Political Science, American University in Cairo.

Brown, N.J., 2011. Dictatorship and Democracy through the Prism of Arab Elections. In: N.J. Brown, ed., The Dynamics of Democratization: Dictatorship, Development, and Diffusion. Baltimore: Johns Hopkins University Press.

Brown, N.J., 2016. Arguing Islam after the Revival of Arab Politics. Oxford University Press.

Brown, N.J., 2017. Saudi Arabia Is Moving to Rein in its Religious Police-Sort of. Washington Post Monkey Cage [online], 16 August. Available from: https://www.washingtonpost.com/news/monkey-cage/wp/2017/08/16/saudi-arabiais-moving-to-rein-in-its-religious-police-sort-of/?utm term=.613ed1e80b01 [Accessed 18 January 2018].

Brown, N.J., 2019. Citizenship, Religious Rights and State Identity in Arab Constitutions: Who is Free and What Are They Free to Do? In: N. Bhuta, ed., Freedom of Religion, Secularism and Human Rights. Oxford University Press, Collected Courses of the Academy of European Law.

Brown, N.J., and Lombardi, C.B., 2006. The Supreme Constitutional Court of Egypt on Islamic Law, Veiling and Civil Rights: An Annotated Translation of Supreme Constitutional Court of Egypt Case No. 8 of Judicial Year 17 (May 18, 1996). American University International Law Review [online], 21(3), 437-460. Available from: https://ssrn.com/abstract=910443 [Accessed 1 March 2019].

Caeiro, A., 2013. Debating the Chaos of Fatwas in the Arab World. Paper presented at the annual meeting of the Middle East Studies Association. New Orleans, 10-13 October.

Cook, M., 2010. Commanding Right and Forbidding Wrong in Islamic Thought. Cambridge University Press.

Dar al-Ifta' al-Misriyya Media Center, 2018. Mufti al-jumhuriyya yubayyin al-ta 'ammul bi1- 'umla al-iliktruniyya 'bitcoin'. Dar al-Ifta' al-Misriyya Media Center [online], 1 January. Available from: http://www.daralifta.org/ar/Viewstatement.aspx?sec=media\&ID=5617 [Accessed 1 March 2019].

Darling, L., 2013. A History of Social Justice and Political Power in the Middle East: The Circle of Justice from Mesopotamia to Globalization. London: Routledge.

El Muhtaseb, L., Brown, N.J., and Kayyali, A.W., 2016. Arguing about Family Law in Jordan: Disconnected Spheres? International Journal of Middle East Studies [online], 48(4), 721-741. Available from: https://doi.org/10.1017/S0020743816000842 [Accessed 1 March 2019].

El-Katiri, M., 2013. The Institutionalization of Religious Affairs: Religious Reform in Morocco. Journal of North African Studies [online], 18(1), 53-69. Available from: https://doi.org/10.1080/13629387.2012.712886 [Accessed 1 March 2019].

Emon, A., 2001. The "Constitution of Medina:" An Essay on Methodology and Ideology in Islamic Legal History. UCLA Journal of Islamic \& Near Eastern Law, 1, 103.

Fox-Decent, E., 2011. Sovereignty's Promise: The State as Fiduciary. Oxford University Press. 
Hallaq, W., 2004. Can the Sharia Be Restored? In: Y.Y. Haddad and B.F. Stowasser, eds., Islamic Law and the Challenges of Modernity. Walnut Creek: Altamira Press.

Hallaq, W., 2014. The Impossible State: Islam, Politics, and Modernity's Moral Predicament. New York: Columbia University Press.

Isma 'il, M., 2016. Memories of the Faraj Foda Case. Islamway [online], 26 September. Available from: https://ar.islamway.net/article/65948/\%D8\%B0\%D9\%83\%D8\%B1\%D9\%8A\%D8\%A7\% D8\%AA-\%D9\%85\%D8\%B9-\%D9\%82\%D8\%B6\%D9\%8A\%D8\%A9\%D9\%81\%D8\%B1\%D8\%AC-\%D9\%81\%D9\%88\%D8\%AF\%D8\%A9, [Accessed 11 January 2018].

Jum'a, 'A., 2008. Al-tajruba al-misriyya. Cairo: Dar Nahdat Misr li-l-Taba`a wa-l-Nashr wa-1Tawzi`.

Lombardi, C.B., and Brown, N.J., 2012. Islam in Egypt's New Constitution. Foreign Policy [online], December / University of Washington School of Law Research Paper [online], $\mathrm{n}$. 2013-19. Available from: https://ssrn.com/abstract=2258252 [Accessed 1 March 2019].

March, A.W., 2015. What Can the Islamic Past Teach Us about Secular Modernity? Political Theory [online] 43(6-December), 838-849. Available from: https://doi.org/10.1177\%2F0090591715606876 [Accessed 1 March 2019].

Mouline, N., 2014. The Clerics of Islam: Religious Authority and Political Power in Saudi Arabia. New Haven: Yale University Press.

Ovamir, A., 2012. Politics, Law, and Community in Islamic Thought: The Taymiyyan Moment. Cambridge University Press.

Shihab al-Din Ahmad ibn Idris al-Qarafi al-Maliki (with Fadel, M.H., trans.), 2017. The Criterion for Distinguishing Legal Opinions from Judicial Rulings and the Administrative Acts of Judges and Rulers (Al-ahkam fi tamyiz al-fatawa 'an al-ahkam wa tasarrufat al-qadi wa-l-imam). New Haven: Yale University Press.

Skovgaard-Petersen, J., 2004. A Typology of State Muftis. In: Y.Y. Haddad and B.F. Stowasser, eds., Islamic Law and the Challenges of Modernity. Walnut Creek: Altamira Press.

Stilt, K., 2012. Islamic Law in Action: Authority, Discretion, and Everyday Experiences in Mamluk Egypt. Oxford University Press.

Sunstein, C., 2007. What the 'Unitary Executive' Debate Is and Is Not About. The University of Chicago Law School Faculty Blog [online], 6 August. Available from; http://uchicagolaw.typepad.com/faculty/2007/08/what-the-unitar.html [Accessed 16 January 2018].

Watt, W.M., 1998. Islamic Political Thought. Edinburgh University Press. 